\title{
An Open Letter to Father Daniel Berrigan
}

\author{
Hillel Levine
}

Vour recent article, "Responses to Settler 1 Regimes" in the October 29, 1973, issue of American Report, came as a shock. The "debt of outraged love" that you claim to be repaying to the Jewish people is not only gratuitous but is downright offensive.

The prisons are full of outraged lovers paying for their crimes of passion. The fondness which you express for the Jewish people makes your assault on truth no less reprehensible. Divorce courts are the last meeting place for lovers whose expectations of each other were based on personal needs rather than mutual understanding.

Like many others, I, too, had expectations of you that are now disappointed. I should have been more suspicious of your self-righteousness, intolerance of ambiguity and prophetic aspirations. But there was an appeal in your fervor which blinded me. For years there had been an ongoing discussion among my friends about the Jewish Dan Berrigan-who is he going to be, or why doesn't he exist? You were a close friend of my beloved teacher, the late Rabbi Abraham Joshua Heschel. It was in his office some seven years ago that we met. You came to convince Heschel that the only tenable moral response to what our government was doing in Vietnam was to go to prison. Heschel asked whether concern for effectiveness should not be part of that moral response. "What type of action will contribute the most to changing America's policy in Vietnam?" he asked.

But for you issues of effectivness were beside the point. To enjoy the rights of a free citizen at this time was itself immoral. Those present were very challenged by your position-as I believe Heschel had intended they would be when he invited several of his students to meet with you. Prison did seem to be a more appropriate place for those who were trying to keep their souls alive in an evil world.

Yet if to put an end to the suffering was ultimately our purpose, could we ignore Heschel's concern for effectiveness-organizations, endless efforts to convince others, the slow-moving and undramatic pursuit of intermittent goals? That night I hedged my bets. I wrote my draft board a letter explaining why
I could no longer cooperate with the Selective Service system, attached it to my draft card and sealed it in an envelope. The next morning as I opened the mail box I could already feel the cold steel of handcuffs on my wrists.

While moved by your position (reinforced during the ensuing years when hearing of your acts of resistance and imprisonment), I also had some reservations about the theological formulations that were at the base of your moral imperatives. Yes, Jeremiah also thought that prison would be the best place for him. But was there something else that you were asserting in your eagerness for martyrdom? Were you not also asking us to bear the cross, or at least bear witness to the cross? I wondered too whether you understood that, for us, the Jewish people is not only a sociological reality but a theological concept as well. Did you understand that a Jewishly informed moral position would, in addition, have to weigh (not be determined by) the plight of Jews in the Soviet Union and the Arab countries and the well-being of Jews in Israel, that within the division of labor for that which is just some would feel called upon to specialize in these causes while at the same time sharing your concerns in a less active way? I no longer wonder.

Shakespeare had something to say of people who protest too much. Heretics, as you style yourself to be, have often been not the innovators but the arch conservatives who seek to restore values and orders long since abandoned. Your attacks on the Jewish people illustrate the dexterity of the ideological imagination that feels no responsibilty to measure iself against reality. Coated in some Third World rhetoric, you present images and conceptions that would make backward, nonheretical Christians squirm.

(Lest you think I welcome the contemporary Jeremiah except when he rails against Israel, let me note that as an associate editor of Worldview I approved the recent publications of articles critical of specific aspects of Israel's policies and would do so again.)

Others have challenged your distorted presentation of the historical background to the conflict of 
Jews and Arabs in the Middle East. Israel is a settler regime, you aver. It is an "imperial adventure" no different from South Africa or even the United States. Does this disturb you because you would like to undo the global population shifts of the past hundreds of years? Or does it disturb you because the Jews now refuse to play the role once prescribed for them by your church, wanderers whose lowliness will testify to their perfidious nature?

Suffice it to say there cannot be the "rational exchange" you call for unless the legitimate national rights of Jews and Arabs are recognized. It is the refusal of the Arabs and their fellow travelers to come to terms with this that has led to war. In this hostile climate Israel, which equated considerations of defense with survival, paid insufficient attention to the problems of Palestinian refugees. And the Arab states did little to alleviate the suffering of the Palestinians.

You speak, too, of injustices inflicted by the State of Israel on some of her citizens. You fail, apparently, to realize that the need to assign the highest priority to defense expenditures prevented the government from dealing directly with the growing social cleavages and economic inequities. Or that the incredible burden of absorbing hundreds of thousands of Jewish refugees whose rights and lives were endangered eroded the egalitarian values of the architects of the State.

In assessing the $1967-73$ period in the history of Israel, it will be the subject of raging debate whether the present government of Israel did all it could to make peace with Arab neighbors. But the stoic shrug of "Ain b'raira," "There is no choice," was repeated not only by-in your terms-avaricious generals and new millionaires. Those who stood most to lose by a GNP of which 40 per cent is mobilized for defense expressed little confidence that unmatched concessions, including the return of occupied Arab territory, wauld insure peace. It was not an inane demand for civility: the Arab refusal of face-to-face recognition and negotiation came to symbolize the denial of legitimacy. You, Father Berrigan, are not making an effective contribution to the resolution of the conflict nor to the solution of Israel's internal problems by questioning her right to exist. In an unredeemed world where nation-states, with all their potential for evil, have proved to be the best structure for the preservation of collective rights and personal liberties, the Jewish people will not be the first to relinquish this protection. Should the world be redeemed and the nature of Man truly changed, neither will they be the last. I know that effectiveness is not your concern, but I thought that truth was.

Your game of "musical identities"-the Arabs should become Jews, the Jews have become "Goyim," certain "Govim" are becoming Jews-would be amusing if there were not a sad.history to the game.
Many people have been moved by the history of Israel and sought to identify with it. The problems begin when the existence of the historical people Israel becomes a disconfirming factor for the wouldbe new Israelites. To be a Jew is not to be your favorite abstraction. It is not to be alienated, to be against the government, or against the Church-all of which you declare yourself to be. To be a Jew is to be part of the Jewish Community, to relate to its past and join in its fate. If our past is an inspiration to you, fine. But you must come to terms with our present existence with more understanding than the Church whose authority you now question did in the past. When the "stigmata" of the wanderers becomes the "stigmata" of the settlers, it is difficult to perceive what has changed.

You assert, as an example of the corrupting effect that Israel and Zionism have had on the Jewish people, that the Jewish leaders and Zionists supported Nixon's policy on Vietnam, "ignoring the Asian holocaust in favor of economic and military aid to Israel." If this morally compromised policy was pursued by some, it certainly did not set the tone for organized Jewish life, nor did it have any influence on the majority of Jews, who, as you yourself point out, vigorously opposed the war. Are you not ashamed to make this false accusation after having had friends in the heart of the Jewish establishment who resisted Nixon's blackmail and tried to expose the lie upon which the comparison of support for Israel and support for Thieu's Vietnam was based?

You state that "in Nixon's first term alone some six-million Southeast Asians had been maimed, bombed, displaced, tortured, imprisoned, or killed. This was one of those peculiar facts which must be called free-floating."

I do not know what "free-floating" facts are. But I do know that I have never seen the number "six million" being used in any authoritative source to describe the devastation which took place in Southeast Asia. The point is not whether there was more or less suffering in Southeast Asia. The number "six million" has very specific associations. Six million were murdered in Europe between 1939 and 1945 , not because they were against their governments nor against their church, but because they were Jews. Will you deny us our tragedy as well as our moral stature? Certain facts cannot be abstracted or universalized.

We welcome the voice of prophets, even if it will encourage false prophets to peddle their vacuous wares. We hope for the continuation of the JewishChristian dialogue conducted with mutual respect and understanding, even if at times we have been deceived into thinking that it is forthcoming. You, Father Berrigan, are in no way a Jew, whatever our relationship with you has been in the past. You conjure up all the fears of the "Goy"-precarious, selfrighteous, irrational and ultimately disloyal. 